\title{
Lipid composition and diet inferences in abyssal macrourids of the eastern North Pacific
}

\author{
Jeffrey C. Drazen ${ }^{1, *}$, Charles F. Phleger ${ }^{2,3}$, Michaela A. Guest ${ }^{4}$, Peter D. Nichols ${ }^{2,3}$ \\ ${ }^{1}$ University of Hawaii, Department of Oceanography, 1000 Pope Road, Honolulu, Hawaii 96822, USA \\ ${ }^{2}$ CSIRO, Marine and Atmospheric Research, Food Futures Flagship, Hobart, Tasmania 7000, Australia \\ ${ }^{3}$ Antarctic and Climate Ecosystems CRC, Hobart, Tasmania 7001, Australia \\ ${ }^{4}$ Tasmanian Aquaculture and Fisheries Institute, Taroona, Nubeena Crescent, Tasmania 7053, Australia
}

\begin{abstract}
The lipid compositions of 2 abyssal macrourids, Coryphaenoides armatus and C. yaquinae, from the eastern North Pacific were examined and used to infer diet. The resulting fatty acid (FA) profiles are the first published for C. yaquinae and among the first for abyssal fishes. They indicated a greater proportion of polyunsaturated FAs and lower monounsaturated FAs than shallower living congeners, suggestive of homeoviscous adaptations to great pressure. Cholesterol was the predominant sterol, which is frequently the case for exclusively carnivorous species. Comparisons of macrourid FA profiles were made to those of benthic prey and epipelagic carrion sources, including the Humboldt squid Dosidicus gigas captured in surface waters of the abyssal study site. The FA profiles of macrourid muscle were very similar to those of squid mantle muscle. The FA profiles of macrourid liver and swimbladder were similar to benthic crustaceans, whole squid, squid digestive gland and the epipelagic fish Trachurus symmetricus. For both tissues, the FA profiles of echinoderms were the most different. These comparisons suggest a strong link to carrion and benthic crustaceans and a weak one to echinoderms, the dominant megafauna at the study site and in most of the abyssal ocean. These results support previous stomach content and stable isotope analyses, reinforcing the hypothesis that there are closer food web ties between abyssal fishes and epipelagic nekton than to many abyssal benthic groups.
\end{abstract}

KEY WORDS: Macrouridae · Deep sea · Trophic ecology · Lipid composition · Sterols · Fatty acid biomarkers $\cdot$ Carrion $\cdot$ Scavenging

Resale or republication not permitted without written consent of the publisher

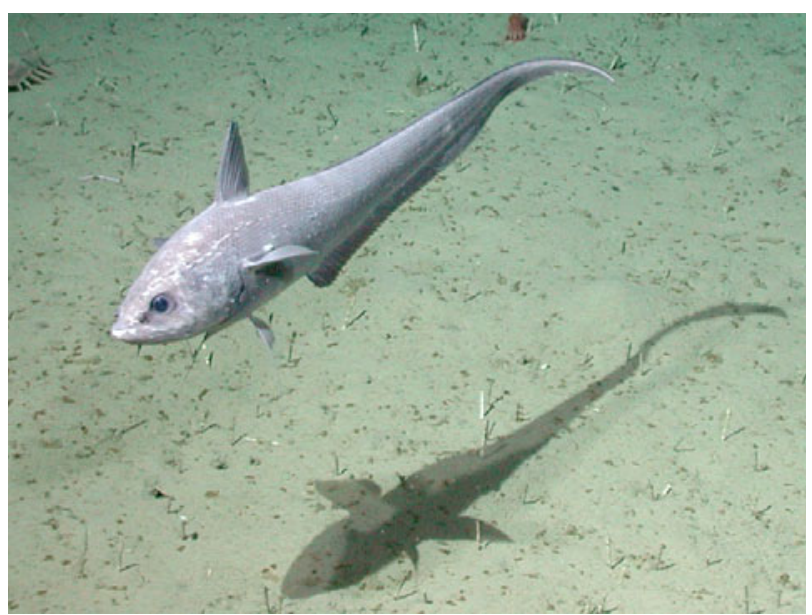

The abyssal grenadier Coryphaenoides armatus feeds predominantly on crustaceans and carrion, and not on echinoderms, which are the most abundant benthic megafauna.

Photo: Monterey Bay Aquarium Research Institute

\section{INTRODUCTION}

The top predators at abyssal depths are primarily fishes. Despite the difficulties of sampling, many studies have investigated their diets and have found a diversity of feeding habits ranging from infaunal browsing to active predation on large nekton (Gartner et al. 1997). By consuming deep-sea prey, these fishes are ultimately dependent upon an allochthonous food supply in the form of phytodetritus generated in surface waters. In simplified terms, phytodetritus is consumed by deposit feeders, which in turn are consumed 
by primary carnivores and so on to the top trophic positions including many fishes. However, an alternative trophic pathway exists. Many deep-sea fishes are attracted to cameras baited with pelagic carrion (Priede \& Bagley 2000, Yeh \& Drazen 2009) and a few studies have noted carrion in their diets (Haedrich \& Henderson 1974, Pearcy \& Ambler 1974, Bjelland et al. 2000). However, these observations have rarely been quantified (Drazen et al. 2001). Scavenging on the sunken carcasses of epipelagic nekton bypasses the conventional benthic food web, although the beginning of each path shares primary production in surface waters. The relative importance of these 2 trophic pathways remains uncertain.

Understanding whether deep-sea fish populations are more closely tied to benthic or epipelagic food supplies is critical for understanding how anthropogenic influences such as fishing and climate change will affect deep-sea ecosystems. Long time-series investigations on the abyssal plains have documented shifts in animal abundances and size frequencies (Billett et al. 2001, Ruhl \& Smith 2004, Bailey et al. 2006), providing insight into possible climate change effects on deep-sea ecosystems. Interdecadal fluctuations in the abundance of 2 abyssal macrourids, Coryphaenoides armatus and C. yaquinae, have been described (Bailey et al. 2006). These species are abundant on the abyssal plains of the eastern North Pacific Ocean and dominate the benthic fish fauna under the California Current (Pearcy et al. 1982, Cailliet et al. 1999). These 2 species are thought to compose the top trophic position in the food web at an abyssal station (Stn M) where the benthic ecosystem has been studied extensively (Smith \& Druffel 1998). Macrourids have swimbladders which expand upon retrieval to the surface causing regurgitation or stomach eversion limiting conventional diet analysis. Stable isotope analyses have been used to augment traditional studies and have found that $C$. armatus and $C$. yaquinae rely heavily on epipelagic carrion and may be more closely tied to epipelagic food supplies (Drazen et al. 2008c).

The use of lipid biomarkers is another alternative methodology which has proven useful in food web studies. Organisms can have unique fatty acid (FA) and sterol compositions, or at least profiles that are traceable, and many of these compounds are transferred from predator to prey without modification (Nichols et al. 1986, Phleger et al. 1998, Dalsgaard et al. 2003). For instance, most animals cannot synthesize long chain $(\geq \mathrm{C} 20$ ) polyunsaturated FAs (LC-PUFAs) such as eicosapentaenoic acid (EPA; 20:503), arachi-

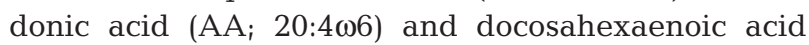
(DHA; 22:6 13 ). Instead these are formed by phytoplankton and some bacteria and are transferred through the food web (Volkman et al. 1989, Brown et al. 1993) such that high levels of these FAs are suggestive of herbivory. Similarly, phytosterols are synthesized only by algae and plants (Volkman 1986, 2003) and are incorporated into herbivores with minimal modification. These types of markers are not exclusively from primary producers. Calanoid copepods have been reported as the major synthesizers for long chain monounsaturated FAs (LC-MUFAs), including the 20:1 and 22:1 isomers, in marine food webs (Sargent \& Whittle 1981). An animal typically has 30 or more FAs and 10 to 20 sterols which can be used to infer such trophic connections. Lipid biomarkers have been used to infer the diet of top trophic level organisms. Their profiles can be compared to potential prey and similarity between profiles implies a trophic connection. For instance, the FA profiles of the southern ocean squid Moroteuthis ingens were most similar to 3 species of myctophids that had been confirmed as their most important prey from diet studies (Phillips et al. 2001). The FA signatures of swordfish and their prey allowed the detection of regional shifts in the predominance of myctophids versus small squids (Young et al. in press). Despite their usefulness, lipid biomarker techniques have only recently been used to examine the trophic ecology of macrourids (Stowasser et al. 2009).

The goal of the present study was to identify and/or infer important prey resources for abyssal macrourids at Stn M in the eastern North Pacific Ocean by (1) determining the lipid composition of the 2 dominant species and (2) comparing their lipid profiles to those of potential benthic prey collected at the same site (Drazen et al. 2008a,b) and carrion sources (Exler \& Weihrauch 1976, Hayashi 1989, Iverson et al. 2002, Aranda et al. 2006, present study).

\section{MATERIALS AND METHODS}

Sampling. All samples were collected at Stn M $\left(34^{\circ} 50^{\prime} \mathrm{N}, 123^{\circ} 00^{\prime} \mathrm{W}, 4100 \mathrm{~m}\right.$ depth) in the northeast Pacific, $220 \mathrm{~km}$ west of Point Conception, California, during August 2006. For a complete description of the physical and biological attributes of this station see Smith \& Druffel (1998). In brief, this site is located on the Monterey Abyssal Fan and lies underneath the California Current. The bottom is flat with sediments composed of fine silt and clay. Particulate matter fluxes to the seafloor show a distinct seasonal cycle following the cycle in surface water productivity. August 2006 represented the peak seasonal flux for the year at $10.26 \mathrm{mg} \mathrm{C} \mathrm{m}^{-2} \mathrm{~d}^{-1}$ (K. Smith pers. comm.).

Specimens of Coryphaenoides armatus and C. yaquinae were collected using a $12.3 \mathrm{~m}$ (width) semiballoon otter trawl and a baited trap. Each specimen was mea- 
sured, weighed and sexed. Macrourids have fragile tail tips which can be broken off naturally or during capture, so length in all cases is pre-anal fin length (PAFL). White muscle is the largest tissue in teleosts and macrourid livers are used for lipid storage, often containing the majority of the fish's lipids (Drazen 2007), so both were sampled for lipid analysis. Macrourid white muscle tissue from under the first dorsal fin and liver tissue from the end of the left lobe was dissected free, placed in cryovials and frozen in liquid nitrogen. The swimbladders of several macrourids are fat-filled with a lipid-rich foam, primarily sterols (Phleger \& Benson 1971), so samples were taken from the interior of the swimbladder.

Common epipelagic nekton such as pacific hake Merluccius productus, jack mackerel Trachurus symetricus and gonatid and ommastrephid squids are potential carrion sources and we sampled some of them using conventional fishing gear in surface waters. Several specimens of the squid Dosidicus gigas were captured. Squid dorsal mantle muscle was sampled in a similar fashion to fish tissues. Tissues were frozen in cryovials under liquid nitrogen on board ship and stored at $-80^{\circ} \mathrm{C}$ in the laboratory. Samples were freeze-dried, ground and then shipped to CSIRO Marine and Atmospheric Research, Hobart, Tasmania, Australia, for lipid analyses. Freeze-dried sample weights, as extracted for lipid, were between 0.02 to $0.39 \mathrm{~g}$, wet weights were 0.1 to $2.0 \mathrm{~g}$.

Lipid extraction. Samples were quantitatively extracted overnight using a modified Bligh \& Dyer (1959) 1-phase methanol:chloroform:water extraction (2:1:0.8 by vol.). The phases were separated by the addition of chloroform:water (final solvent ratio, 1:1:0.9 by vol. methanol:chloroform:water). The total solvent extract (TSE) was concentrated using rotary evaporation at $40^{\circ} \mathrm{C}$.

Lipid classes. An aliquot of the TSE was analysed using an Iatroscan MK V TH10 thin-layer chromatography-flame ionization detector (TLC-FID) to quantify individual lipid classes (Fraser et al. 1985, Volkman \& Nichols 1991). Samples were applied in duplicate to silica gel SIII chromarods ( $5 \mu \mathrm{m}$ particle size) using $1 \mu \mathrm{l}$ micropipettes. Chromorods were developed in a glass tank lined with pre-extracted filter paper. The primary solvent system for lipid separation was hexane:diethyl ether:acetic acid (60:17:0.1), a mobile phase resolving non-polar compounds such as wax ester (WE), triacylglycerol (TAG), free fatty acids (FFAs) and sterols (STs) from phospholipid (PL). A second non-polar solvent system of hexane:diethyl ether (96:4) resolved hydrocarbons from WE, and TAG from diacylglycerol ether (DAGE). After development, the chromorods were oven-dried and analysed immediately to minimize absorption of atmospheric contaminants. The FID was calibrated for each lipid class (phosphatidylcholine, cholesterol, cholesteryl oleate, oleic acid, squalene, TAG [derived from fish oil], WE [derived from orange roughy Hoplostethus atlanticus oil] and DAGE [derived from shark liver oil]; 0.1 to $10 \mu \mathrm{g}$ range). Peaks were quantified on an IBM compatible computer using DAPA Scientific software. TLC-FID results are generally reproducible to $\pm 10 \%$ of individual lipid class abundances (Volkman \& Nichols 1991).

Fatty acids. An aliquot of the TSE was trans-methylated to produce fatty acid methyl esters (FAMEs) using methanol:chloroform:concentrated hydrochloric acid $\left(10: 1: 1,80^{\circ} \mathrm{C}, 2 \mathrm{~h}\right.$; Christie 1982). FAMEs were extracted into hexane:chloroform $(4: 1,3 \times 1.5 \mathrm{ml})$. FAME fractions were treated with $\mathrm{N}, \mathrm{O}$-bis-(trimethylsilyl)trifluoroacetamide (BSTFA $50 \mu \mathrm{l}, 60^{\circ} \mathrm{C}$, overnight) to convert STs, alcohols and hydroxyl FAs to their corresponding trimethylsilyl ethers.

Gas chromatographic (GC) analyses were performed with an Agilent Technologies 6890N GC equipped with an HP-5 cross-linked methyl silicone fused silica capillary column (50 $\mathrm{m} \times 0.32 \mathrm{~mm}$ inner diameter), an FID, a split/splitless injector and an Agilent Technologies 7683 Series auto sampler and injector. Helium was the carrier gas. Following addition of methyl nonodecanoate internal injection standard, samples were injected in splitless mode at an oven temperature of $50^{\circ} \mathrm{C}$. After $1 \mathrm{~min}$, the oven temperature was raised to $150^{\circ} \mathrm{C}$ at $30^{\circ} \mathrm{C} \mathrm{min}{ }^{-1}$, then to $250^{\circ} \mathrm{C}$ at $2^{\circ} \mathrm{C} \mathrm{min}{ }^{-1}$ and finally to $300^{\circ} \mathrm{C}$ at $5^{\circ} \mathrm{C} \mathrm{min}^{-1}$. Peaks were quantified with Agilent Technologies GC ChemStation software. Individual components were identified using mass spectral data and by comparing retention time data with those obtained for authentic and laboratory standards. GC results are subject to an error of $\pm 5 \%$ of individual component area as determined by replicate analysis. GC-mass spectrometric (GC-MS) analyses were performed on a Finnigan Thermoquest GCQ GCmass spectrometer fitted with an on-column injector using Thermoquest Xcalibur software. The GC was fitted with a capillary column similar to that described above.

Statistical analysis. FA profiles of the macrourids were compared to each other and between tissue types using principal component analysis (PCA). PCA reduces the number of dimensions produced by the large number of variables and uses linear correlations (components) to identify those FAs that contribute most to the separation between observed groups (Best et al. 2003). FAs that contributed a mean of less than $1.0 \%$ (of total FAs) to the profile were omitted from statistical analyses. All analyses were performed on percent composition data and results were confirmed by analysis of $\mathrm{mg} \mathrm{g}^{-1}$ FA data (data not shown, see also Phillips et al. 2003). The first 2 principal components (PCs) 
were plotted on the $x$ - and $y$-axes with FAs contributing most to the separation on each axis shown with arrows indicating the direction in which that FA generally increases in proportion (Best et al. 2003).

To augment the PCA results, a hierarchical cluster analysis was performed on a Bray-Curtis similarity matrix of specimen FA profiles. Clusters were overlaid on the PCA plots to assist in the interpretation of similarity and grouping between samples (Clarke \& Gorley 2006). The clusters represent percent similarity and the groups result from taking a slice through a clustering tree at a particular level of similarity. All statistical analyses were performed using Primer 6 software (Primer-E).

FA profiles of the macrourids were also compared to those of potential prey taxa using PCA. Data for benthic animals were taken from Drazen et al. $(2008 a, b)$ and include a variety of species (holothurians: Abyssocucumis abyssorum, Oneirophanta mutabilis, Peniagone vitrea, Protankyra brychia; ophiuroids: Ophiocantha sp., Ophiura bathybia; polychaetes: Laetmonice sp., Paradiopatra sp., Travisia sp.; cnidarians: Bathyphelia nomados; crustaceans: Munidopsis sp., 1 caridean shrimp, 2 lysianassid amphipod species). Some of these animals have been found in the macrourids' stomachs and others are amongst the dominant megafauna at the abyssal station (Lauerman et al. 1996, Ruhl 2007, Drazen et al. 2008c). These samples were collected at the same site and at the same time as the macrourids. As noted above we were only able to collect one squid species, Dosidicus gigas, to represent carrion sources for the macrourids. To augment the data, FA profiles of epipelagic fish and squid were obtained from the literature for species which have been found in macrourid stomachs from this site (Drazen et al. 2008c). These include jack mackerel Trachurus symmetricus (Aranda et al. 2006), pacific hake Merluccius productus (Exler \& Weihrauch 1976) and the gonatid squid Gonatopsis borealis (Hayashi 1989). The macrourids also consumed other squid species and we included data for 2 other gonatids, Berryteuthis magister and an unidentified gonatid (Iverson et al. 2002). Not all of the studies reported the location of the first double bond in the FA, but all reported the chain length and saturation state; for the PCA analyses incorporating published data, our FA profiles were condensed accordingly (i.e. 18:107, 18:1 $\omega 9$, etc. were lumped to total 18:1).

\section{RESULTS}

\section{Lipid composition}

Coryphaenoides armatus examined were 15.5 to $22.5 \mathrm{~cm}$ PAFL and C. yaquinae were 12.0 to $20 \mathrm{~cm}$ PAFL. Dosidicus gigas were 25.6 to $33.5 \mathrm{~cm}$ mantle length. The lipid content of C. armatus and C. yaquinae muscle and $D$. gigas mantle muscle was much lower than that of macrourid liver and swimbladder foam (Table 1). Lipid composition of tissues low in total lipid were primarily membrane-bound PL and ST with minor amounts of energy storage lipids such as TAG and WE. The lipids in the livers of both macrourid species were primarily TAG (58 to $61 \%$ ), although this was variable between replicate specimens and was directly correlated to total lipid content $(\% \mathrm{TAG}=1.41 \times$ lipid content $\left.-11.76, \mathrm{n}=7, \mathrm{r}^{2}=0.96, \mathrm{p}<0.05\right)$. Swimbladder foam consisted of ca. two-thirds PL and one-third ST. Diacylglyceryl ether was detected at low levels in swimbladder foam of $C$. yaquinae, but not in any other samples. Cholesterol (cholest-5-en-3 $\beta$-ol) comprised almost all of the ST in macrourid tissues and D. gigas

Table 1. Coryphaenoides armatus, C. yaquinae and Dosidicus gigas. Lipid content and composition of the abyssal macrourid fishes $C$. armatus and $C$. yaquinae (muscle, liver and swimbladder foam) and the squid D. gigas. Values are means \pm SD. $\mathrm{n}$ : number of specimens analyzed for a particular tissue; WE: wax ester; DAGE: diacylglyceryl ether; TAG: triacylglycerol; FFA: free fatty acid; ST: sterol; PL: phospholipid

\begin{tabular}{|c|c|c|c|c|c|c|c|c|}
\hline \multirow[t]{2}{*}{ Species } & \multirow[t]{2}{*}{$\mathrm{n}$} & \multicolumn{6}{|c|}{ — composition- } & \multirow{2}{*}{$\begin{array}{l}\text { Lipid content } \\
\% \text { dry wt }\end{array}$} \\
\hline & & WE & DAGE & TAG & FFA & $\mathrm{ST}$ & PL & \\
\hline \multicolumn{9}{|l|}{ Macrourid fishes } \\
\hline \multicolumn{9}{|l|}{ C. armatus } \\
\hline Muscle & 4 & $0 \pm 0$ & $0 \pm 0$ & $1.4 \pm 1.3$ & $0.7 \pm 0.4$ & $3.1 \pm 1.2$ & $94.8 \pm 2.1$ & $3.5 \pm 0.9$ \\
\hline Liver & 3 & $0.9 \pm 1.6$ & $0 \pm 0$ & $57.7 \pm 46.8$ & $10.3 \pm 11.4$ & $2 \pm 2.7$ & $29.1 \pm 47.6$ & $47.4 \pm 31.7$ \\
\hline Swimbladder foam & 1 & 0 & 0 & 0.6 & 1 & 33.7 & 64.7 & 48.4 \\
\hline \multicolumn{9}{|l|}{ C. yaquinae } \\
\hline Muscle & 3 & $1.6 \pm 1.6$ & $0 \pm 0$ & $0.5 \pm 0.2$ & $2.2 \pm 0.4$ & $2.6 \pm 0.9$ & $93.1 \pm 1.1$ & $3.1 \pm 0.9$ \\
\hline Liver & 4 & $4.3 \pm 1.8$ & $0 \pm 0$ & $61.2 \pm 36.6$ & $14.5 \pm 13.2$ & $0.4 \pm 0.3$ & $19.6 \pm 31.2$ & $53.2 \pm 26.0$ \\
\hline Swimbladder foam & 1 & 0.6 & 0.7 & 0.5 & 0.7 & 32.7 & 64.9 & 54.5 \\
\hline \multicolumn{9}{|l|}{ Squid } \\
\hline D. gigas & 5 & $0.9 \pm 0.1$ & $0 \pm 0$ & $0 \pm 0$ & $4.3 \pm 4.3$ & $11.4 \pm 1.9$ & $83.4 \pm 5.1$ & $3.5 \pm 0.3$ \\
\hline
\end{tabular}


Table 2. Coryphaenoides armatus, C. yaquinae and Dosidicus gigas. Sterol (\%) composition of the abyssal macrourids C. armatus and $C$. yaquinae and the squid D. gigas. Values are means \pm SD. Swimbf: swimbladder foam

\begin{tabular}{|c|c|c|c|c|c|c|c|}
\hline \multirow[t]{2}{*}{ Sterol } & \multicolumn{3}{|c|}{ C. armatus -} & \multicolumn{3}{|c|}{ C. yaquinae -} & \multirow{2}{*}{$\begin{array}{l}\text { D. gigas } \\
\text { mantle }\end{array}$} \\
\hline & Muscle & Liver & Swimbf & Muscle & Liver & Swimbf & \\
\hline 24 -norcholesta-5, 22E-dien-3 $\beta$-ol & $0.2 \pm 0.3$ & $0.2 \pm 0.3$ & 0.4 & $0.3 \pm 0.3$ & $0 \pm 0$ & 0.3 & $0 \pm 0$ \\
\hline cholesta-5, 22Z-dien-3 $\beta$-ol & $0.1 \pm 0.2$ & $0 \pm 0$ & 0.2 & $0 \pm 0$ & $0 \pm 0$ & 0.2 & $0.1 \pm 0.1$ \\
\hline cholesta-5, 22E-dien-3 $\beta$-ol & $0.5 \pm 0.5$ & $0.1 \pm 0.2$ & 0.5 & $0.2 \pm 0.3$ & $0 \pm 0$ & 0.5 & $1.1 \pm 0.2$ \\
\hline 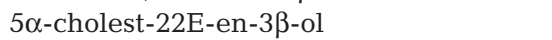 & $1.4 \pm 0.2$ & $0.6 \pm 1$ & 1.7 & $1.5 \pm 0.1$ & $0.4 \pm 0.7$ & 1.5 & $1.8 \pm 0.2$ \\
\hline 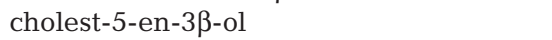 & $97.4 \pm 1.6$ & $97.8 \pm 2$ & 95.5 & $97.5 \pm 0.9$ & $99.3 \pm 1.4$ & 93.8 & $94.9 \pm 0.8$ \\
\hline $5 \alpha$-cholestan- $3 \beta$-ol & $0.2 \pm 0.3$ & $0.1 \pm 0.3$ & 0.5 & $0.3 \pm 0.3$ & $0 \pm 0$ & 0.5 & $0.1 \pm 0.2$ \\
\hline 24-methylcholesta-5, 24(28)E-dien-3 $\beta$-ol & $0 \pm 0$ & $0.1 \pm 0.2$ & 0.4 & $0 \pm 0$ & $0.1 \pm 0.3$ & 0.9 & $0 \pm 0$ \\
\hline 24-methylcholest-5en-3ß-ol & $0 \pm 0$ & $0 \pm 0$ & 0.1 & $0 \pm 0$ & $0 \pm 0$ & 0.6 & $0 \pm 0$ \\
\hline 23,24 -dimethylcholesta-5, 22E-dien-3 $\beta$-ol & $0 \pm 0$ & $0 \pm 0$ & 0.2 & $0 \pm 0$ & $0 \pm 0$ & 0.7 & $0.3 \pm 0.1$ \\
\hline 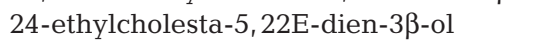 & $0.3 \pm 0.6$ & $1 \pm 1.7$ & 0.0 & $0 \pm 0$ & $0 \pm 0$ & 0.0 & $0 \pm 0$ \\
\hline 24-ethylcholest-5-en-3 $\beta$-ol & $0 \pm 0$ & $0 \pm 0$ & 0.0 & $0 \pm 0$ & $0 \pm 0$ & 0.1 & $0 \pm 0$ \\
\hline Other sterols & $0 \pm 0$ & $0.2 \pm 0.3$ & 0.5 & $0.2 \pm 0.3$ & $0.2 \pm 0.4$ & 1.0 & $1.8 \pm 0.5$ \\
\hline
\end{tabular}

(Table 2). $5 \alpha$-cholest-22E-en-3 $\beta$-ol was 0.4 to $2 \%$ and there were several other STs as minor components.

Total PUFA comprised $\geq 50 \%$ of the FAs in Coryphaenoides armatus, C. yaquinae, and Dosidicus gigas muscle; values were lower in liver and lowest in swimbladder (Fig. 1). Conversely, MUFAs were highest in liver and swimbladder foam and lowest in muscle and squid mantle. Total saturated FAs (SFAs) were similar amongst tissues, but were lowest in macrourid liver tissue and highest in $D$. gigas mantle.

The FA profiles of macrourid muscle and squid mantle were similar (Table 3). The PUFA docosahexaenoic acid (DHA, 22:6 63 ) was the most abundant FA in macrourid muscle and squid mantle; lower levels were found in macrourid liver and it comprised only a few percent of total FA in the swimbladder. EPA $(20: 5 \omega 3)$ was also abundant ( 8 to $13 \%)$ in macrourid muscle and squid mantle with comparable levels in liver, but it comprised only a few percent of total FA in the swimbladder. The third most abundant PUFA was arachidonic acid (AA, 20:4 $\omega 6$ ) which comprised 2 to $5 \%$ of total FA in all macrourid tissues and 1\% in Dosidicus gigas. The PUFA docosapen-

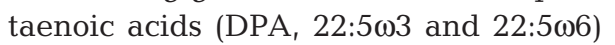
were present in all tissues in small amounts. The major MUFAs in the muscle of the fishes were $18: 1 \omega 7 \mathrm{c}$ and $18: 1 \omega 9 \mathrm{c}$, which were also abundant MUFAs in the squid mantle, but less so than 20:109c. Macrourid liver and swimbladder MUFA was primarily 18:1 $\omega 9 \mathrm{c}$ with appreciable proportions of $16: 1 \omega 7 \mathrm{C}$,

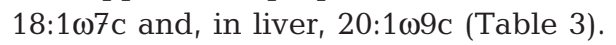
Palmitic acid (16:0) was the principal SFA component (Table 3). There was more 16:0 in muscle and swimbladder foam of both macrourid species than in the liver, with the greatest proportion found in D. gigas mantle $(27 \%)$. Stearic acid (18:0) comprised 4 to $5 \%$ of total FA in muscle of both macrourids and 2 to $3 \%$ in liver and swimbladder foam, while comprising $6 \%$ in squid. Myristic acid (14:0) levels were 6 to $7 \%$ of total FA in swimbladder foam, with relatively low levels in the other macrourid tissues and squid. The odd-carbon FA 17:0 was low $(0.2$ to $0.4 \%)$ in all macrourid tissues and $1 \%$ in squid. Branched chain SFAs (bacterial FA markers) i15:0, a15:0, i17:0 and a17:0 were also low in all samples $(0.2$ to $1 \%$ of total FA) (Table 3).

Differences in the FA profiles of the macrourid tissues were clearly represented by PCA (Fig. 2). Four groups were evident at the $75 \%$ similarity level:

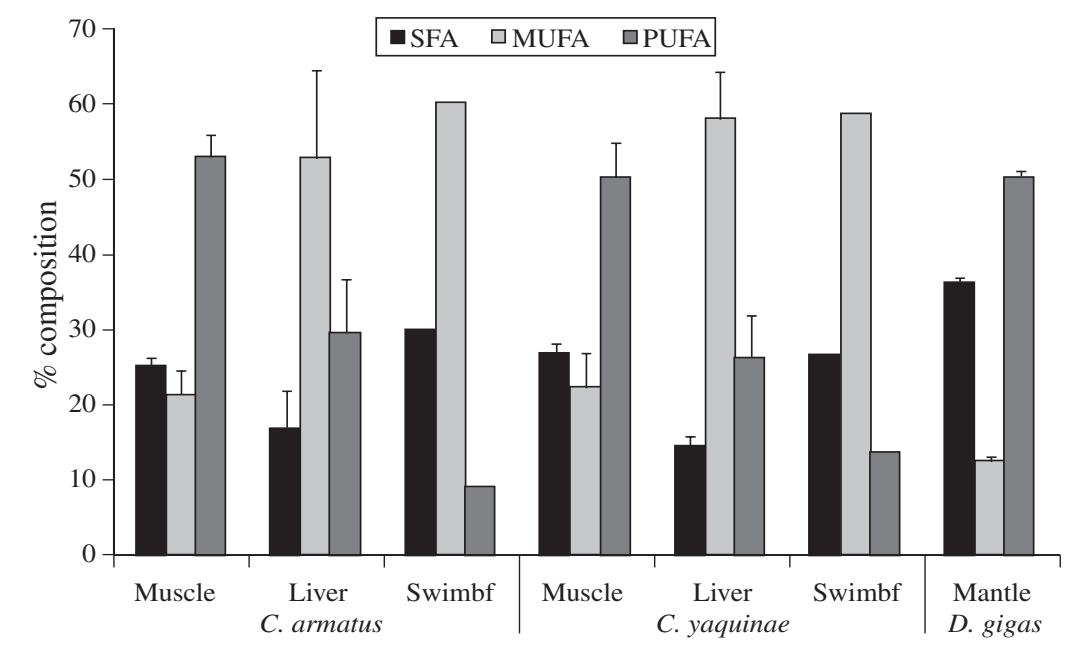

Fig. 1. Coryphaenoides armatus, C. yaquinae and Dosidicus gigas. Saturated, monounsaturated and polyunsaturated fatty acid (SFA, MUFA, PUFA respectively) percent composition by tissue type (muscle, liver, swimbladder foam [swimbf] and mantle) for abyssal macrourid fishes Coryphaenoides armatus and C. yaquinae and squid D. gigas. Values are means $\pm \mathrm{SD}$ 
Table 3. Coryphaenoides armatus, C. yaquinae and Dosidicus gigas. Fatty acid (FA) composition (\% of total fatty acids) of the abyssal macrourids $C$. armatus and $C$ yaquinae and the squid D. gigas. Values are means \pm SD. Swimbf: swimbladder foam; AA: arachidonic acid; EPA: eicosapentaenoic acid: GED: glyceryl ether diol; NMI: nonmethylene interrupted; DPA: docosapen-

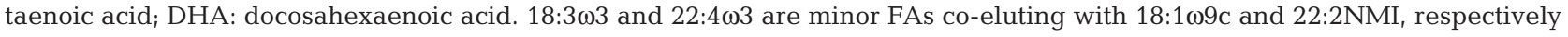

\begin{tabular}{|c|c|c|c|c|c|c|c|}
\hline \multirow{2}{*}{ FA } & \multicolumn{3}{|c|}{ C. armatus } & \multicolumn{3}{|c|}{-C. yaquinae -} & \multirow{2}{*}{$\begin{array}{l}\text { D. gigas } \\
\text { Mantle }\end{array}$} \\
\hline & Muscle & Liver & Swimbf & Muscle & Liver & Swimbf & \\
\hline $14: 0$ & $0.3 \pm 0.1$ & $0.6 \pm 0.2$ & 6.1 & $0.3 \pm 0.1$ & $0.8 \pm 0.3$ & 6.7 & $0.8 \pm 0.1$ \\
\hline $15: 0$ & $0.2 \pm 0$ & $0.2 \pm 0$ & 0.4 & $0.3 \pm 0.1$ & $0.4 \pm 0.1$ & 0.7 & $0.4 \pm 0$ \\
\hline $16: 0$ & $19.1 \pm 0.9$ & $11.7 \pm 2.6$ & 19.6 & $21.3 \pm 1.8$ & $9.3 \pm 1.5$ & 15.2 & $27.2 \pm 0.7$ \\
\hline $16: 1 \omega 5 c$ & $0.2 \pm 0$ & $0.2 \pm 0$ & 0.3 & $0.6 \pm 0.4$ & $0.5 \pm 0.3$ & 0.6 & $0.1 \pm 0$ \\
\hline $16: 1 \omega 7 \mathrm{C}$ & $1.4 \pm 0.4$ & $5.9 \pm 3.1$ & 11.4 & $1.8 \pm 0.5$ & $8.5 \pm 2.9$ & 12.8 & $0.3 \pm 0.1$ \\
\hline $16: 1 \omega 9 \mathrm{c}$ & $0.2 \pm 0.1$ & $0.6 \pm 0.1$ & 0.8 & $0.3 \pm 0.3$ & $0.7 \pm 0.1$ & 0.7 & $0 \pm 0$ \\
\hline $17: 0$ & $0.3 \pm 0.1$ & $0.2 \pm 0.2$ & 0.4 & $0.4 \pm 0.1$ & $0.3 \pm 0.2$ & 0.4 & $1.1 \pm 0.1$ \\
\hline a17:0 & $0.2 \pm 0$ & $0.2 \pm 0.1$ & 0.6 & $0.3 \pm 0.1$ & $0.7 \pm 0.4$ & 0.0 & $0.1 \pm 0$ \\
\hline i17:0 & $0.1 \pm 0$ & $0.2 \pm 0$ & 0.3 & $0.2 \pm 0.1$ & $0.5 \pm 0.2$ & 0.5 & $0.1 \pm 0$ \\
\hline $17: 1 \omega 8 \mathrm{c}$ & $0.3 \pm 0.1$ & $0.6 \pm 0.2$ & 1.0 & $0.3 \pm 0.1$ & $1 \pm 0.2$ & 1.2 & $0.1 \pm 0$ \\
\hline br17:1 & $0.1 \pm 0$ & $0.1 \pm 0$ & 0.8 & $0.1 \pm 0.1$ & $0.1 \pm 0$ & 0.7 & $0 \pm 0$ \\
\hline 18:0 & $5 \pm 0.2$ & $3.3 \pm 2.2$ & 2.3 & $3.9 \pm 0.1$ & $1.5 \pm 0.5$ & 2.0 & $5.9 \pm 0.1$ \\
\hline $18: 1 \omega 5 \mathrm{c}$ & $0.1 \pm 0$ & $0.4 \pm 0.1$ & 0.5 & $0.4 \pm 0.3$ & $0.9 \pm 0.5$ & 0.8 & $0.1 \pm 0$ \\
\hline $18: 1 \omega 7 \mathrm{c}$ & $3.4 \pm 0.6$ & $7.5 \pm 1$ & 3.8 & $3.3 \pm 0.8$ & $7.5 \pm 1.8$ & 5.8 & $1.4 \pm 0.2$ \\
\hline $18: 1 \omega 9 c$ & $10.8 \pm 2.5$ & $24.7 \pm 10.5$ & 29.0 & $8.7 \pm 1.3$ & $22.5 \pm 4.7$ & 23.6 & $1.7 \pm 0.2$ \\
\hline $18: 2 \omega 6$ & $0.5 \pm 0.1$ & $0.9 \pm 0.2$ & 0.8 & $0.4 \pm 0.1$ & $1.1 \pm 0.2$ & 0.8 & $0.1 \pm 0$ \\
\hline 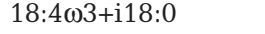 & $0.2 \pm 0$ & $0.5 \pm 0.2$ & 0.2 & $0.1 \pm 0$ & $0.7 \pm 0.2$ & 0.4 & $0.2 \pm 0$ \\
\hline $19: 1 b$ & $0.2 \pm 0.1$ & $0.3 \pm 0.1$ & 0.1 & $0.3 \pm 0.1$ & $0.5 \pm 0.1$ & 0.3 & $0.2 \pm 0$ \\
\hline $20: 1 \omega 7 \mathrm{c}$ & $0.2 \pm 0.1$ & $0.6 \pm 0.3$ & 0.5 & $1.7 \pm 1.7$ & $3.4 \pm 2.6$ & 1.8 & $0.2 \pm 0$ \\
\hline $20: 1 \omega 9 c$ & $2.2 \pm 0.5$ & $5.9 \pm 0.4$ & 2.2 & $2.5 \pm 0.1$ & $6.7 \pm 1.2$ & 1.8 & $6.2 \pm 0.5$ \\
\hline $20: 1 \omega 11 \mathrm{c}$ & $0.4 \pm 0.4$ & $1 \pm 1$ & 1.7 & $0.1 \pm 0.1$ & $1.5 \pm 1.2$ & 0.6 & $0 \pm 0$ \\
\hline $20: 2 \omega 6$ & $0.2 \pm 0.2$ & $0.5 \pm 0.3$ & 0.0 & $0.4 \pm 0.1$ & $0.7 \pm 0.5$ & 0.0 & $0.2 \pm 0$ \\
\hline $20: 4 \omega 3$ & $0.2 \pm 0$ & $0.5 \pm 0.2$ & 0.1 & $0.3 \pm 0$ & $0.7 \pm 0.3$ & 0.2 & $0.1 \pm 0$ \\
\hline 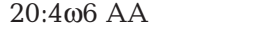 & $4.6 \pm 0.5$ & $2.6 \pm 1.7$ & 2.4 & $3.7 \pm 0.3$ & $2.8 \pm 1.5$ & 2.2 & $0.9 \pm 0.2$ \\
\hline 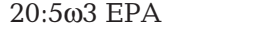 & $9.4 \pm 1.1$ & $8.6 \pm 0.4$ & 2.6 & $7.1 \pm 1.8$ & $8.5 \pm 0.5$ & 3.1 & $12.7 \pm 0.4$ \\
\hline $22: 1 \omega 7 \mathrm{C}$ & $0 \pm 0$ & $0.1 \pm 0.1$ & 0.3 & $0.2 \pm 0.1$ & $0.2 \pm 0.2$ & 0.6 & $0.1 \pm 0.1$ \\
\hline $22: 1 \omega 9 \mathrm{c}+16: 0$ GED & $0.7 \pm 0.1$ & $1.6 \pm 1.2$ & 2.3 & $0.9 \pm 0.1$ & $1.2 \pm 0.6$ & 3.0 & $1.4 \pm 0.1$ \\
\hline $22: 1 \omega 11+13 c$ & $0.2 \pm 0.1$ & $0.7 \pm 0.3$ & 2.4 & $0.1 \pm 0.1$ & $0.9 \pm 0.5$ & 0.9 & $0.1 \pm 0$ \\
\hline 22:2NMI & $0.1 \pm 0$ & $0.1 \pm 0.2$ & 0.1 & $0.2 \pm 0$ & $0.4 \pm 0.1$ & 0.3 & $0.1 \pm 0$ \\
\hline $22: 4 \omega 6$ & $0.5 \pm 0.2$ & $0.4 \pm 0.1$ & 0.0 & $0.8 \pm 0.2$ & $0.5 \pm 0.2$ & 0.3 & $0.2 \pm 0.1$ \\
\hline 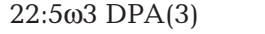 & $1.8 \pm 0.2$ & $1.3 \pm 0.3$ & 0.4 & $2 \pm 0.5$ & $2 \pm 0.6$ & 1.1 & $0.6 \pm 0$ \\
\hline 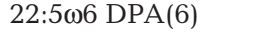 & $0.6 \pm 0$ & $0.2 \pm 0.1$ & 0.1 & $0.5 \pm 0.1$ & $0.3 \pm 0.1$ & 0.2 & $0.4 \pm 0.1$ \\
\hline 22:6ஸ3 DHA & $34.8 \pm 3.5$ & $13.9 \pm 5.3$ & 2.4 & $34.6 \pm 7.4$ & $8.6 \pm 3.1$ & 5.0 & $34.8 \pm 0.9$ \\
\hline $24: 1 \mathrm{a}$ & $0 \pm 0$ & $0 \pm 0$ & 0.6 & $0 \pm 0$ & $0 \pm 0$ & 0.2 & $0 \pm 0$ \\
\hline $24: 1 b$ & $0.8 \pm 0.2$ & $1.7 \pm 2$ & 2.4 & $0.6 \pm 0.2$ & $0.8 \pm 0.7$ & 2.1 & $0.4 \pm 0.1$ \\
\hline Other & $0.6 \pm 0.2$ & $2 \pm 0.7$ & 1.1 & $1.4 \pm 0.6$ & $3.6 \pm 1.3$ & 3.3 & $1.9 \pm 0.1$ \\
\hline
\end{tabular}

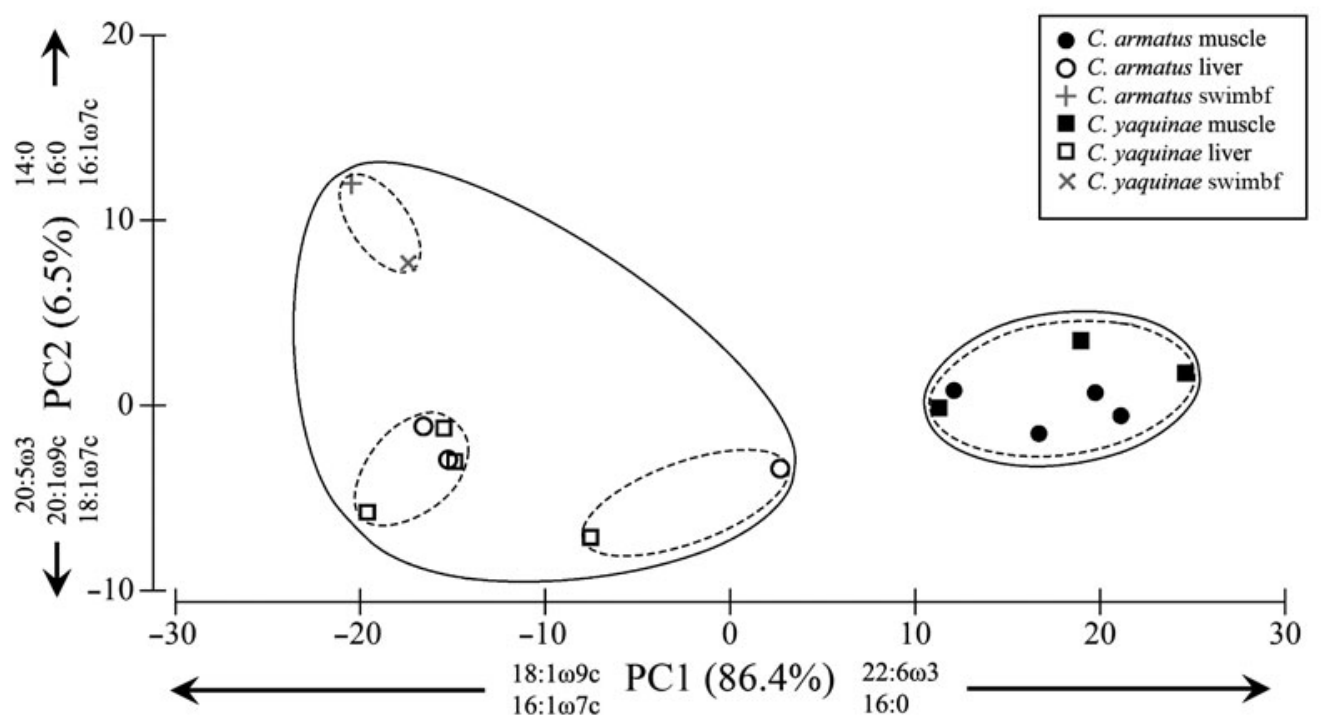

Fig. 2. Coryphaenoides armatus and C. yaquinae. Biplot of the first and second principal components (PC) derived from the fatty acid composition of abyssal macrourid tissues (muscle, liver and swimbladder foam [swimbf]). Arrows on axes indicate fatty acids contributing most to the distribution of species along each component. Ellipses around samples indicate hierarchical clustering (using a Bray-Curtis similarity matrix); (-): $\geq 60 \%$ or (-- ): $\geq 75 \%$ similarity 
muscle, swimbladder foam and 2 liver groups. Muscle tissue was most clearly distinguished from liver and swimbladder foam along PC1, which explained $86.4 \%$ of the total variance. FAs that contributed most to the separation of groups along PC1 were 22:6 $13,16: 0$,

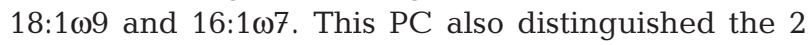
liver groups. The 2 specimens with PC1 scores closer to zero, one Coryphaenoides armatus and one $C$. yaquinae, had greater proportions of DHA and 16:0 than the rest of the specimens. Both of these specimens had low liver TAG compared to species averages (15\% TAG for C. armatus and $20 \%$ for C. yaquinae). PC2 explained $6.5 \%$ of the total variance and separated swimbladder foam from liver tissue. The FAs contributing most to the separation of tissue types along PC2 were $14: 0,16: 0,16: 1 \omega 7 c, 20: 5 \omega 3 c, 20: 1 \omega 9 c$ and $18: 1 \omega 7 \mathrm{C}$.

\section{Comparison of macrourid lipid profiles to potential prey}

The macrourid FA profiles were compared to those of benthic prey (Drazen et al. 2008a,b) and Dosidicus gigas from the present study using PCA (Fig. 3). This data set represents the macrourids and their prey captured at the same location and time and FA profiles analyzed with the same methods and level of FA profile detail. PC1 explained most of the variance $(45.7 \%)$ and distinguished the macrourid and squid (D. gigas) muscle tissue from the benthic animals, macrourid swimbladder tissue and most liver tissue samples. FAs that contributed the most to the separation of groups along PC1 were $22: 6 \omega 3,16: 0, \alpha \mathrm{OH} 24: 1$ and $18: 1 \omega 9 \mathrm{c}$, such that the macrourid and squid muscle samples were very high in

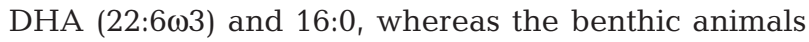
were very low in DHA and 16:0 but had more 18:1 $19 \mathrm{C}$ and $\alpha \mathrm{OH} 24: 1$. The macrourid liver samples were generally low in DHA and 16:0. One Coryphaenoides armatus specimen had a liver with low \% TAG and lipid content and its FA profile clustered separately from the others (Fig. 2), intermediate between the rest of the liver samples and the muscle samples along PC1 (Fig. 3). PC2 explained $24.2 \%$ of the variance in FA profiles. Crustacean FA profiles were distinct from those of the echinoderms (ophiuroids and holothuroids) and the polychaetes' profiles were intermediate between these 2 taxa. Macrourid liver and swimbladder profiles were similar to each other and to the crustaceans. The C. armatus and C. yaquinae specimens with liver profiles (both with low TAG) which clustered separately from the other liver samples (Fig. 2) were more similar to the macrourid muscle and D. gigas profiles along PC2 (Fig. 3). The major FAs contributing to separations along this axis were $\alpha \mathrm{OH} 24: 1,20: 5 \omega 3,23: 1,18: 1 \omega 9 \mathrm{c}$, $16: 1 \omega 7 \mathrm{c}$ and $16: 0$.
At the $60 \%$ similarity level, the macrourid and squid muscle FA profiles clustered together. Macrourid liver and swimbladder foam profiles clustered with the crustaceans and the anemone. The macrourid tissues were most different from the echinoderm and polychaete profiles. At a $75 \%$ similarity level, the 2 macrourid liver groups were evident and separate from that of the swimbladder foam, which clustered with the amphipods' profile. The polychaete and echinoderm profiles formed clusters which were separate from the profiles of any of the macrourid tissues.

PCA analysis was also used with additional data for epipelagic nekton/carrion sources from the literature (Exler \& Weihrauch 1976, Hayashi 1989, Iverson et al. 2002, Aranda et al. 2006). PCA was performed on condensed FA profiles as described in the 'Materials and methods' (Fig. 4). The results were very similar to the analysis without published data (Fig. 3), with relative relationships between macrourids and benthic animals remaining the same. PC1 explained most of the variance $(54.4 \%)$ and the major FAs contributing to this

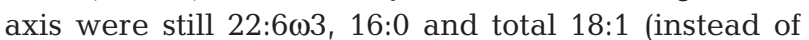
$18: 1 \omega 9 \mathrm{c}$ as in the above analysis) with the addition of total 16:1 and total 20:1. The major FAs contributing to PC2 were also similar to the analysis conducted on the detailed FA profiles. The macrourid muscle FA profiles continued to group tightly with $D$. gigas's mantle muscle profile, but also with the profiles for whole Gonatidae and mantle muscle of other squid species. All of the epipelagic nekton FA profiles grouped around the origin of PC2 along with the macrourid muscle (Fig. 4). The 2 epipelagic fishes, Merluccius productus and Trachurus symmetricus, had profiles that were intermediate between those of the benthic animals (and macrourid livers) and the macrourid muscle along PC1. Gonatopsis borealis liver and whole Berryteuthis magister profiles had the most negative PC1 scores for the epipelagic nekton and were more similar to FA profiles of macrourid liver and benthic animals along this axis.

The cluster analysis showed much greater similarity between groups than the analysis with the detailed profiles, as would be expected (compare Figs. 3 \& 4). Macrourid muscle FA profiles clustered with the squid mantle profiles (Dosidicus gigas, Gonatopsis borealis and Berryteuthis magister) as well as with whole Gonatidae specimens (Fig. 4). At the $60 \%$ similarity level, profiles of macrourid liver and swimbladder foam clustered with those of squid liver tissue, whole $B$. magister and the benthic taxa (except for the holothurians, which formed 2 separate clusters). At the $75 \%$ similarity level, macrourid liver and swimbladder foam profiles were clustered with amphipod profiles. FA profiles of the 2 specimens with low liver lipid clustered with profiles for the anemone, the epipelagic fish Trachurus symmetricus, squid liver samples and whole B. magister. 

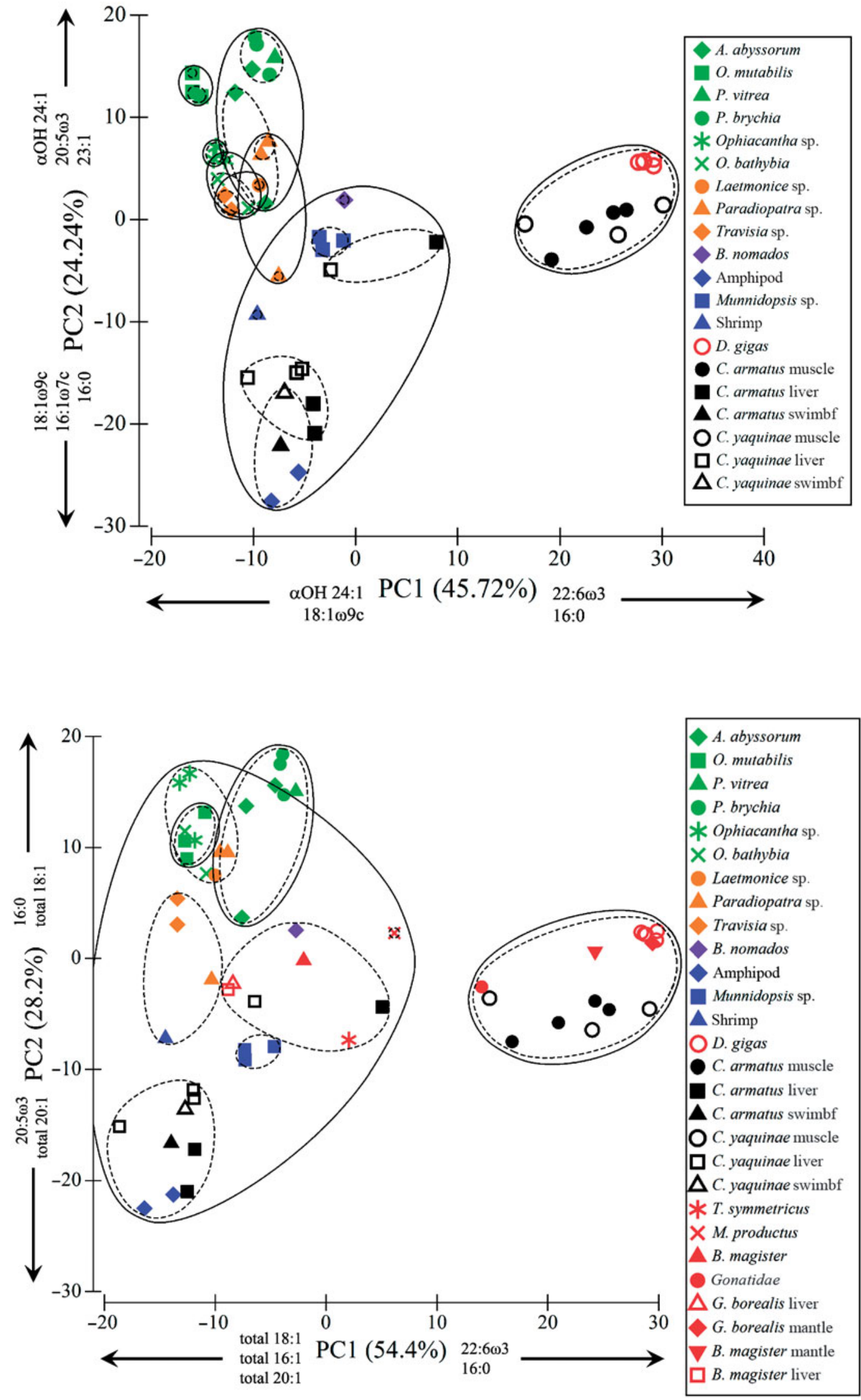

Fig. 3. Biplot of the first and second principal components (PC) derived from the fatty acid composition of abyssal macrourids, benthic animals and the epipelagic squid Dosidicus gigas. Symbols are colorcoded by general taxonomic category: echinoderms (green), polychaetes (orange), anemones (purple), crustaceans (blue), epipelagic nekton/potential carrion (red) and macrourids (black). Arrows on axes indicate fatty acids contributing most to the distribution of species along each component. Ellipses around samples indicate hierarchical clustering (using a Bray-Curtis similarity matrix); (-): $\geq 60 \%$ or (- - ): $\geq 75 \%$ similarity. Swimbf: swimbladder foam
Fig. 4. Biplot of the first and second principal components (PC) derived from the fatty acid composition of abyssal macrourids, benthic prey and pelagic food sources from the literature. FA profiles from the present study were condensed to match those in the literature (see 'Materials and methods'). Color codes are as in Fig. 3. Arrows on axes indicate fatty acids contributing most to the distribution of species along each component. Ellipses around samples indicate hierarchical clustering (using a Bray-Curtis similarity matrix); (-): $\geq 60 \%$ or (- - ): $\geq 75 \%$ similarity. Swimbf: swimbladder foam 


\section{DISCUSSION}

\section{Macrourid lipids}

The lipid class analysis of the 2 macrourid species was in agreement with past studies of these and other species in the genus (Drazen 2002b, 2007, Hayashi \& Kishimura 2003). Muscle was low in lipid which was predominantly $\mathrm{PL}$; in contrast, roughly half the dry weight of the livers was lipid which was predominantly TAG (Table 1). TAG is an energy storage lipid that is easy to metabolize and thus is considered useful for short-term energy storage. The high variation in macrourid liver lipid content (correlated to \% TAG) at any given time (see SD in Table 1; Drazen 2002b) is probably the result of individual variation in foraging success, particularly if sporadic but often large parcels such as carrion are consumed (Drazen 2002b). This energy storage strategy may help sustain these fishes between sporadic scavenging events (Drazen 2002a).

The FA profiles of Coryphaenoides armatus and C. yaquinae are very similar to those found in other abyssal macrourids and morids including specimens of C. armatus from the northeast Atlantic (Stowasser et al. 2009). Despite collections in different years and ocean basins, the FA profiles of $C$. armatus between the present study and that of Stowasser et al. (2009) are similar, with roughly similar proportions of all the major FAs. However, the Pacific macrourids have greater proportions of EPA and lower proportions of DHA than the Atlantic specimens. Regional and temporal variation in phytoplankton dynamics likely results in different proportions of these essential FAs entering the pelagic and subsequently benthic food webs.

The FA profiles of Coryphaenoides armatus and $C$. yaquinae differed from those of other shallower-living macrourids in several ways. Total muscle PUFAs of C. armatus and C. yaquinae were greater than $50 \%$, higher than values for C. acrolepis (44\%), C. cinereus $(40 \%)$ and C. pectoralis (38\%), and total MUFAs were similar (Hayashi \& Kishimura 2003). PUFA values were also higher in comparison to C. macrocephalus collected at $\sim 1600 \mathrm{~m}$ near a hydrothermal vent field (Guerreiro et al. 2004). DHA was $\sim 8 \%$ higher in $C$. armatus and C. yaquinae, but EPA values were comparable to these other Coryphaenoides species. PUFAs in the cell membranes are used to maintain lipid bilayer fluidity under high pressure and/or cold temperatures (Hochachka \& Somero 2002). Thus the differences in total PUFA between these species likely reflect the shallower collection depth $(400 \mathrm{~m})$ of the species in Hayashi \& Kishimura's (2003) study. Total PUFA in muscle for C. acrolepis collected off San Diego, California, from depths to $1000 \mathrm{~m}$, comprised $35 \%$ of total FA (Lewis 1967), and both DHA and EPA were lower than the upper slope species examined by Hayashi \& Kishimura (2003). The lower total PUFA, DHA and EPA values in C. acrolepis, and thus also higher proportions of total MUFA, may reflect loss of PUFA on the polyester and nonpolar columns as discussed by Lewis (1967).

The liver FA profiles of Coryphaenoides armatus and C. yaquinae were very different than those from the muscle, with lower PUFA and higher MUFA. This difference has been observed in other macrourids and morids (Stowasser et al. 2009). This may reflect the large proportions of TAG compared to the PL-dominated muscle tissue (Table 1). The 2 individuals (1 C. armatus and $1 C$. yaquinae) with lower \% TAG in their livers did have FA profiles more similar to muscle (Fig. 3). Hayashi \& Kishimura (2003) examined macrourid liver lipids and found somewhat different FA profiles for TAG and PL intraspecifically. Their liver TAG profiles were similar to those we present for total liver lipids, except that 22:1 isomers were present in greater proportions in their study. However, their liver PL profiles were very low in total PUFA $(<10 \%)$ and DHA and high in MUFA (42 to $52 \%$ ), more similar to liver TAG and very unlike the profiles for muscle PL in their study or total muscle (primarily PL) in the present study. This suggests that lipid class composition is not the only determinant of the FA profiles. Differences between the profiles of liver and muscle likely reflect lipid physiology as well as diet.

Cholesterol was the major ST component of macrourid muscle and liver, as is frequently the case for vertebrates including fish who obtain cholesterol directly from their diet and other means, such as phytosterol dealkylation and synthesis of cholesterol within cells (Nichols et al. 1986). $5 \alpha$-cholest-22E-en-3 $\beta$-ol, the second most abundant ST (Table 2), is an intermediate in cholesterol synthesis although it could also derive from animal prey. Phytosterols, which indicate a diet of plant material or detritus, are abundant in the echinoderms (Drazen et al. 2008a), anemone and polychaetes (Drazen et al. 2008b) from Stn M. Their absence in the macrourid diet is as expected for top carnivores.

Coryphaenoides armatus and C. yaquinae fill their swimbladders with lipids, primarily cholesterol, as do many other macrourids (Phleger \& Benson 1971, Bowne 1982). This is the first report of cholesterol-rich foam in the swimbladder of $C$. yaquinae. In deep-sea fishes whose swimbladders are not ruptured by decompression, the lipid-rich deposit appears as a thick lining coating the entire bladder interior. Gas glands are embedded in this lining (Bowne 1982). The term 'foam' was used to describe the decompressed swimbladder contents in C. acrolepis after sampling from great ocean depths (Patton \& Thomas 1971). The lipid foam is rich in cholesterol and PL as reported in many 
deep-sea benthopelagic fishes including C. acrolepis, C. abyssorum, C. cf. fernandezianus, Antimora rostrata, and a number of brotulid fishes (Phleger 1991). The cholesterol and PLs are organized into gram quantities of pure bilayer membrane which probably function as a buoyancy mechanism by facilitating oxygen secretion at depth (pressure).

There are few FA analyses for swimbladder foam and the profiles presented here are the first for Coryphaenoides armatus and C. yaquinae. They revealed comparatively low PUFAs including the essential FAs DHA (2 to $5 \%$ ) and EPA (3\%). High MUFA content was reflected by 18:1 (all isomers, 30 to $33 \%$ ) and 16:1 (both isomers, 12 to $13 \%$ ). These levels are different than those found for the congener $C$. acrolepis from 700 to $1900 \mathrm{~m}$ depth, which had higher total PUFAs, and 48 to $50 \%$ of 18:1 (Phleger \& Benson 1971). C. cf. fernandezianus and Spectrunculus grandis (a brotulid called Parabassogigas sp. in Phleger \& Benson 1971) from abyssal depths (3400 to $4600 \mathrm{~m}$ ) off Chile also had higher total PUFAs, essential PUFAs (10 to $13 \% \mathrm{DHA}, 3$ to $9 \% \mathrm{EPA}$ ) and 18:1 (all isomers 41 to $42 \%$ ) compared to C. armatus and C. yaquinae swimbladder foam (Phleger \& Holtz 1973). It is not clear why these differences exist, but they could reflect diet or variation in the requirement for swimbladder function.

\section{Dosidicus gigas lipids}

The lipids of Dosidicus gigas were very similar to those of other oceanic squid. The low lipid content and predominance of PLs in the mantle tissue analysed was similar to that of Gonatus antarcticus, Moroteuthis robsoni and Todarodes spp. from the Southern Ocean (Phillips et al. 2002). In contrast, the digestive gland, which many squid species use as the primary site of lipid storage, contained 22 to $54 \%$ lipid which was 42 to $80 \%$ TAG (Phillips et al. 2002). As for many upper trophic level fishes and squid (Goad 1978, Phillips et al. 2001), the sterol profile of $D$. gigas was almost wholly cholesterol. Squid can synthesize cholesterol, but probably obtain most from their diet rich in fish.

The FA composition of Dosidicus gigas is broadly similar to that for the mantle tissue of many other oceanic squid. For instance, the total PUFA of the Southern Ocean squid species Sepioteuthis australis, Gonatus antarcticus, Moroteuthis robsoni and Todarodes spp. was 52 to $58 \%$ (Phillips et al. 2002), compared to $50 \%$ in D. gigas. Levels of DHA and EPA were likewise similar. The same was true for Gonatopsis borealis from the North Pacific (Hayashi 1989). Low total MUFA in D. gigas (13\%) was also characteristic of the 4 Southern Ocean squid species (10 to $22 \%$; Phillips et al. 2002) and G. borealis (13\%; Hayashi 1989).
The mantle of Dosidicus gigas and other squid species have FA profiles very different from that of digestive gland tissue, which has large amounts of TAG and other storage lipids. Digestive glands of several squid species were lower in total PUFAs (23 to $43 \%$ ) with less DHA (8 to 19\%) and less EPA (6 to $13 \%$ ) than mantles (Hayashi 1989, Phillips et al. 2002). Iverson et al. (2002), working in the subpolar North Pacific, examined the lipids in whole squid, incorporating both mantle and digestive gland. Berryteuthis magister, Rossia pacifica and an unidentified gonatid contained 35 to $48 \%$ total PUFA consisting of 15 to $25 \%$ DHA and 10 to $19 \%$ EPA. Total MUFAs were higher in these squid (26 to $47 \%$ ) than in D. gigas, and SFA was relatively lower (18 to $26 \%$ ) (Iverson et al. 2002). These values are intermediate between the mantle and digestive gland data as would be expected. Unfortunately, there are no data for the FA profiles of PL and TAG in digestive glands as there were for macrourid livers, so it is not presently clear whether the differences between mantle and liver FA profiles are driven primarily by differences in lipid class composition. The implications of the tissuespecific FA differences on food web studies are discussed below.

\section{Macrourid diet inferred from fatty acid profiles}

A major aim of the present study was to utilize FA profiles to ascertain the diet of Coryphaenoides armatus and C. yaquinae, particularly the importance of epipelagic carrion. This approach has been used for a number of marine invertebrates, fishes, marine mammals and squid (Phleger et al. 1998, Buhring \& Christiansen 2001, Nelson et al. 2001, Phillips et al. 2001, 2003, Best et al. 2003, Herman et al. 2005, Guest et al. 2008), and has become increasingly recognized in recent times by marine researchers as an approach that can complement other methods.

The FA profiles of Coryphaenoides armatus and $C$. yaquinae specimens were very similar to each other, implying very similar sources of nutrition. Both species also had similar isotopic compositions, but stomach content analysis suggests differences in diet. From stomach contents, both species appeared to feed regularly on amphipods, but C. armatus fed more on squid, fish, and carrion and C. yaquinae more on polychaetes, other crustaceans and to some extent on the burrowing holothurian Protankyra brychia (Drazen et al. 2008c). The differences may be the result of low sample sizes in the diet analysis and the fact that stomachs only record the last few feeding events. It is also possible that variation in consumption of low-lipid prey (polychaetes, echinoderms) has little impact on the FA 
profiles, but sharing common high-lipid prey (i.e. amphipods, fish) results in similar profiles.

While the FA profiles of the 2 macrourid species were similar, the FA profiles of muscle, liver and swimbladder foam were not and the physiological reasons for these differences have been addressed above. For the present dietary purposes, the swimbladder foam profiles are likely unimportant because the swimbladder has a very slow lipid turnover time (Phleger et al. 1977) and it is not related to nutritional status as are the liver and muscle (Black \& Love 1986, Drazen 2002b). The swimbladder lipids are organized into bilayer membranes and, as they have a structural role, their turnover is slower than that of liver and muscle (Phleger \& Holtz 1973). Comparison of liver and muscle tissue FA profiles to those of potential prey should provide meaningful dietary insights.

Comparison of the FA profiles of a range of potential prey items (Drazen et al. 2008a,b) and muscle tissue for the 2 macrourids grouped the macrourids closely with the mantle tissue of epipelagic squid and whole gonatid squid, and clearly separated them from all benthic fauna (Figs. $3 \& 4$ ). The echinoderms contained a number of novel FAs (i.e. 23:1, 24:1, $\alpha \mathrm{OH} 23: 1$, $\alpha \mathrm{OH} 24: 1, \mathrm{C} 24$ and C26 PUFA; Drazen et al. 2008a) which were not detected in the macrourids, but this is not the only reason for their separation from the macrourids. PCA analysis using condensed data excluded these novel FAs and generally provided the same groupings (Fig. 4). Furthermore, from this comparison of analyses, it is evident in this case that little information is lost by condensing our detailed information into the broad FA categories for comparisons to published data. The close grouping of macrourid and squid muscle is consistent with pelagic squid being a major dietary item and/or these animals having a similar diet. Considering the disparate habitats of the macrourids and squid, the latter proposal is unlikely. Furthermore, isotopic evidence suggests dietary differences between the macrourids and Dosidicus gigas (Drazen et al. 2008c), and diet studies of D. gigas and gonatids show that mesopelagic myctophids and other micronekton are the most important prey (Nesis 1997, Markaida et al. 2008), animals which are unlikely available to macrourids on the abyssal plain. Even though the squid FA profiles (except for D. gigas) came from specimens captured in different North Pacific locations at different times, they all clustered closely together (Fig. 4), clearly illustrating that they provide a reliable FA profile for the group.

Analysis with macrourid liver FA profiles provides a less exclusive perspective. Most macrourid lipids are contained in the liver (Drazen 2007), whose content appears dynamic, suggesting tight coupling to feeding and nutritional status. The liver FA profiles are most closely grouped with those of lysianassid amphipods and secondarily with the other benthic crustaceans (Figs. 3 \& 4). The 2 macrourid specimens with lower $\%$ TAG than the rest had liver FA profiles that grouped closely to epipelagic fishes and squid (digestive gland tissue and whole). Both liver groups were separated from echinoderms, suggesting that this benthic group plays a small role in the diet of Coryphaenoides armatus and $C$. yaquinae. These diet inferences match well with conventional diet analysis and stable isotopic analysis (Drazen et al. 2008c). Macrourids are known to feed on squid (Gonatopsis borealis and gonatids) and epipelagic fishes (Trachurus symmetricus and Merluccius productus) as carrion. Only Protankyra brychia, a burrowing vermiform holothurian, has been found in the guts of $C$. armatus and $C$. yaquinae in the North Pacific (Pearcy \& Ambler 1974, Drazen et al. 2008c). Generally, macrourids do not eat many echinoderms (Pearcy \& Ambler 1974, Stein 1985, Martin \& Christiansen 1997) even though they are very abundant and dominate the epibenthic megafauna in most abyssal habitats and at Stn M (Lauerman et al. 1996). Absence of echinoderms in acidic macrourid stomachs is probably not an artifact resulting from rapid digestion because the few echinoderms found in stomach contents are mostly carbonate-rich ophiurids (Pearcy \& Ambler 1974, Drazen et al. 2001) and the present FA results do not suggest they are eaten to any great extent. In addition, Feller et al. (1985), using crossreacting antisera techniques with $C$. armatus intestinal fluids from $2500 \mathrm{~m}$ in the western Atlantic, found evidence for consumption of holothurians, but not other echinoderms. Macrourids may ignore them because of their low caloric density and high carbonate content (Billett 1991) or avoid them because of toxicity or distastefulness (Stonik et al. 1999). Whichever the case, the macrourids appear not to feed on a numerically dominant benthic animal group but upon benthic crustaceans and the allochthonous supply of nekton carcasses from the epipelagic. Stowasser et al. (2009) also found evidence of benthic prey and carrion from FA profiles, but were unable to identify which specific types of benthic organisms might have been ingested.

Clearly, FA profiles differ between tissue types of both fishes and squid, and the whole animal FA profiles lie in between. For the macrourids, whole animal values would likely be closer to the values for liver. The differences in FA profiles between tissues are probably not simply the result of differences in the lipid class composition as discussed above and also examined by lipid class-specific FA analysis in other species of macrourids (Hayashi \& Kishimura 2003). Instead, diet may play a role. In this case, liver profiles may be more indicative of recent feeding, in this case on benthic crustaceans, with muscle most likely inte- 
grating feeding history over a much longer time span, suggesting carrion as a major trophic input. Future work should focus on whole animal analysis for at least some samples (Iverson et al. 2002), although the large differences in FA profiles between the macrourid tissues and echinoderms should not be affected.

Intuitively, food web studies of abyssal ecosystems often connect the epibenthic megafauna, primarily echinoderms, with top level consumers such as fishes (Smith 1992, Bailey et al. 2006). Previous stomach content and isotope analyses have suggested that these 2 macrourid species bypass much of the benthic food web and rely nutritionally upon dead fish and squid sinking from surface waters instead (Drazen et al. 2008c). Results from the present study clearly suggest the absence of echinoderms as prey and the importance of carrion, as well as the importance of benthic crustaceans to the macrourids' diet. Bailey et al. (2006) suggested that while variation in macrourid abundance covaried with that of echinoderms, it may be other taxa, more important as prey yet not as visible in their camera sled surveys, which are responsible for the population trends observed. Our findings suggest that benthic crustaceans would be the most likely candidate. The dynamics of carrion supply are also likely important to understanding abyssal fish dynamics. Carrion supply may change in response to increases in fishing pressure and consequent discards (Votier et al. 2004), be reduced as epipelagic stocks are depleted (Sibert et al. 2006) or simply shift in composition as species such as the Humboldt squid Dosidicus gigas expand their range into the North Pacific (Zeidberg \& Robison 2007). The present study supports the notion that anthropogenic impacts in epipelagic ecosystems could be rapidly transferred to top trophic levels in the abyssal ocean.

Acknowledgements. We thank K. L. Smith for the opportunity to participate on cruise Pulse 49 aboard the RV 'Atlantis' to Station $M$, and the cruise participants for their assistance with sample collection and processing. D. Holdsworth managed the CSIRO GC-MS facility. This research was supported by funding from the School of Ocean and Earth Science and Technology, University of Hawaii to J.C.D.

\section{LITERATURE CITED}

Aranda M, Mendoza N, Villegas R (2006) Lipid damage during frozen storage of whole jack mackerel (Trachurus symmetricus murphyi). J Food Lipids 13:155-166

Bailey DM, Ruhl HA, Smith KL Jr (2006) Long-term change in benthopelagic fish abundance in the abyssal NE Pacific Ocean. Ecology 87:549-555

Best NJ, Bradshaw CJA, Hindell MA, Nichols PD (2003) Vertical stratification of fatty acids in the blubber of southern elephant seals (Mirounga leonina): implications for diet analysis. Comp Biochem Physiol B 134:253-263
Billett DSM (1991) Deep-sea holothurians. Oceanogr Mar Biol Annu Rev 29:259-317

Billett DSM, Bett BJ, Rice AL, Thurston MH, Galeron J, Sibuet M, Wolff GA (2001) Long-term change in the megabenthos of the Porcupine Abyssal Plain (NE Atlantic). Prog Oceanogr 50:325-348

Bjelland O, Bergstad OA, Skjaeraasen JE, Meland K (2000) Trophic ecology of deep-water fishes associated with the continental slope of the eastern Norwegian Sea. Sarsia 85:101-117

Black D, Love RM (1986) The sequential mobilisation and restoration of energy reserves in tissues of Atlantic cod during starvation and refeeding. J Comp Physiol B 156: 469-479

Bligh EG, Dyer WJ (1959) A rapid method of total lipid extraction and purification. Can J Biochem Physiol 37:911-917

Bowne PS (1982) Swimbladder deposits: occurrence and morphology in Macrouridae, Moridae and Ophidiiformes. Copeia 1982:205-208

Brown MR, Dunstan GA, Jeffrey SW, Volkman JK, Barrett SM, LeRoi JM (1993) The influence of irradiance on the biochemical composition of the pyrmnesiophyte Isochrsis sp. (clone t-iso). J Phycol 29:601-612

Buhring SI, Christiansen B (2001) Lipids in selected abyssal benthopelagic animals: Links to the epipelagic zone? Prog Oceanogr 50:369-382

Cailliet GM, Andrews AH, Wakefield WW, Moreno G, Rhodes KL (1999) Fish faunal and habitat analyses using trawls, camera sleds and submersibles in benthic deep-sea habitats off central California. Oceanol Acta 22:579-592

Christie WW (1982) Lipid analysis. Pergamon Press, Oxford

Clarke KR, Gorley RN (2006) PRIMER v6: user manual and tutorial. PRIMER-E, Plymouth

Dalsgaard J, St John M, Kattner G, Muller-Navarra D, Hagen W (2003) Fatty acid trophic markers in the pelagic marine environment. Adv Mar Biol 46:225-340

> Drazen JC (2002a) Energy budgets and feeding rates of Coryphaenoides acrolepis and C. armatus. Mar Biol 140: $677-686$

Drazen JC (2002b) A seasonal analysis of the nutritional condition of deep-sea macrourid fishes in the north-east Pacific. J Fish Biol 60:1280-1295

> Drazen JC (2007) Depth related trends in proximate composition of demersal fishes in the eastern North Pacific. DeepSea Res I 54:203-219

> Drazen JC, Buckley TW, Hoff GR (2001) The feeding habits of slope dwelling macrourid fishes in the eastern North Pacific. Deep-Sea Res I 48:909-935

> Drazen JC, Phleger CF, Guest MA, Nichols PD (2008a) Lipid, sterols and fatty acid composition of abyssal holothurians and ophiuroids from the north-east Pacific Ocean: food web implications. Comp Biochem Physiol B 151:79-87

> Drazen JC, Phleger CF, Guest MA, Nichols PD (2008b) Lipid, sterols and fatty acids of abyssal polychaetes, crustaceans, and a cnidarian from the northeast Pacific Ocean: food web implications. Mar Ecol Prog Ser 372:157-167

Drazen JC, Popp BN, Choy CA, Clemente T, De Forest LG, Smith KL (2008c) Bypassing the abyssal benthic food web: macrourid diet in the eastern North Pacific inferred from stomach content and stable isotopes analyses. Limnol Oceanogr 53:2644-2654

> Exler J, Weihrauch JL (1976) Comprehensive evaluation of fatty acids in foods. J Am Diet Assoc 69:243-248

> Feller RJ, Zagursky G, Day EA (1985) Deep-sea food web analysis using cross-reacting antisera. Deep-Sea Res A 32: 485-497

Fraser AJ, Tocher DR, Sargent JR (1985) Thin-layer chro- 
matography-flame ionization detection and the quantitation of marine neutral lipids and phospholipids. J Exp Mar Biol Ecol 88:91-99

Gartner JV, Crabtree RE, Sulak KJ (1997) Feeding at depth. In: Randall DJ, Farrell AP (eds) Deep-sea fishes. Academic Press, San Diego, CA, p 115-193

Goad LJ (1978) The sterols of marine invertebrates: composition, biosynthesis, and metabolites. In: Scheuer PJ (ed) Marine natural products: chemical and biological perspectives. Academic Press, New York, p 75-172

Guerreiro V, Narciso L, Almeida A, Biscoito M (2004) Fatty acid profiles of deep-sea fishes from the Lucky Strike and Menez Gwen hydrothermal vent fields (Mid-Atlantic Ridge). Cybium 28:33-44

Guest MA, Nichols PD, Frusher SD, Hirst AJ (2008) Evidence of abalone (Haliotis rubra) diet from combined fatty acid and stable isotope analyses. Mar Biol 153:579-588

Haedrich RL, Henderson NR (1974) Pelagic food of Coryphaenoides armatus, a deep benthic rattail. Deep-Sea Res Oceanogr Abstr 21:739-744

Hayashi K (1989) Occurrence of diacyl glyceryl ethers in liver lipids of gonatid squid Gonatopsis borealis. Nippon Suisan Gakkai Shi 55:1383-1387

Hayashi K, Kishimura H (2003) Amount of squalene and fatty acid composition of triacylglycerols and phospholipids in flesh and liver lipids of some deep-sea teleost fish, morid cods and whiptails. J Oleo Sci 52:339-345

Herman DP, Burrows DG, Wade PR, Durban JW and others (2005) Feeding ecology of eastern North Pacific killer whales Orcinus orca from fatty acid, stable isotope, and organochlorine analyses of blubber biopsies. Mar Ecol Prog Ser 302:275-291

Hochachka PW, Somero GN (2002) Biochemical adaptation: mechanism and process in physiological evolution. Oxford University Press, Oxford

Iverson SJ, Frost KJ, Lang SLC (2002) Fat content and fatty acid composition of forage fish and invertebrates in Prince William Sound, Alaska: factors contributing to among and within species variability. Mar Ecol Prog Ser 241:161-181

Lauerman LML, Kaufmann RS, Smith KL Jr (1996) Distribution and abundance of epibenthic megafauna at a long time-series station in the abyssal Northeast Pacific. DeepSea Res I 43:1075-1103

Lewis RW (1967) Fatty acid composition of some marine animals from various depths. J Fish Res Board Can 24: 1101-1115

Markaida U, Salinas-Zavala CA, Rosas-Luis R, Gilly WF, Booth JAT (2008) Food and feeding of jumbo squid Dosidicus gigas in the central Gulf of California during 20052007. Calif Coop Ocean Fish Invest Rep 49

Martin B, Christiansen B (1997) Diets and standing stocks of benthopelagic fishes at two bathymetrically different midoceanic localities in the Northeast Atlantic. Deep-Sea Res I 44:541-558

Nelson MM, Mooney BD, Nichols PD, Phleger CF (2001) Lipids of Antarctic Ocean amphipods: food chain interactions and the occurrence of novel biomarkers. Mar Chem 73:53-64

Nesis KN (1997) Gonatid squids in the subarctic north Pacific: ecology, biogeography, niche diversity and role in the ecosystem. Adv Mar Biol 32:243-324

Nichols PD, Klumpp DW, Johns RB (1986) A study of food chains in seagrass communities. IX. Lipid components and utilization by consumers of a seagrass community: an indication of carbon source. Comp Biochem Physiol B 83: 103-113
Patton S, Thomas AJ (1971) Composition of lipid foams from swim bladders of two deep ocean fish species. J Lipid Res 12:331-335

Pearcy WG, Ambler JW (1974) Food habits of deep-sea fishes off the Oregon coast. Deep-Sea Res 21:745-759

Pearcy WG, Stein DL, Carney RS (1982) The deep-sea benthic fish fauna of the northeastern Pacific Ocean on Cascadia and Tufts abyssal plains and adjoining continental slopes. Biol Oceanogr 1:375-428

Phillips KL, Jackson GD, Nichols PD (2001) Predation on myctophids by the squid Moroteuthis ingens around Macquarie and Heard Islands: stomach contents and fatty acid analyses. Mar Ecol Prog Ser 215:179-189

> Phillips KL, Nichols PD, Jackson GD (2002) Lipid and fatty acid composition of the mantle and digestive gland of four Southern Ocean squid species: implications for food-web studies. Antarct Sci 14:212-220

Phillips KL, Jackson GD, Nichols PD (2003) Temporal variations in the diet of the squid Moroteuthis ingens at Macquarie Island: stomach contents and fatty acid analyses. Mar Ecol Prog Ser 256:135-149

Phleger CF (1991) Biochemical aspects of buoyancy in fishes. In: Hochachka PW, Mommsen TP (eds) Biochemistry and molecular biology of fishes. Elsevier Science Publishers, Amsterdam, p 209-247

Phleger CF, Benson AA (1971) Cholesterol and hyperbaric oxygen in swimbladders of deep sea fishes. Nature 230:122

Phleger CF, Holtz RB (1973) The membranous lining of the swim-bladder in deep sea fishes. I. Morphology and chemical composition. Comp Biochem Physiol B 45:867-873

Phleger CF, Holtz RB, Grimes PW (1977) Membrane biosynthesis in swimbladders of deep sea fishes Coryphaenoides acrolepis and Antimora rostrata. Comp Biochem Physiol B 56:25-30

Phleger CF, Nichols PD, Virtue P (1998) Lipids and trophodynamics of Antarctic zooplankton. Comp Biochem Physiol B 120:311-323

Priede IG, Bagley PM (2000) In situ studies on deep-sea demersal fishes using autonomous unmanned ladder platforms. Oceanogr Mar Biol Annu Rev 38:357-392

Ruhl HA (2007) Abundance and size distribution dynamics of abyssal epibenthic megafauna in the northeast Pacific. Ecology 88:1250-1262

Ruhl HA, Smith KL Jr (2004) Shifts in deep-sea community structure linked to climate and food supply. Science 305: 513-515

Sargent JR, Whittle JJ (1981) Lipids and hydrocarbons in the marine food web. In: Longhurst AR (ed) Analysis of marine ecosystems. Academic Press, London, p 491-553

Sibert J, Hampton J, Kleiber P, Maunder M (2006) Biomass, size, and trophic status of top predators in the Pacific Ocean. Science 314:1773-1776

Smith KL Jr (1992) Benthic boundary layer communities and carbon cycling at abyssal depths in the central North Pacific. Limnol Oceanogr 37:1034-1056

Smith KL Jr, Druffel ERM (1998) Long time-series monitoring of an abyssal site in the NE Pacific: an introduction. DeepSea Res II 45:573-586

Stein DL (1985) Towing large nets by single warp at abyssal depths: Method and biological results. Deep-Sea Res A 32: 183-200

- Stonik VA, Kalinin VI, Avilov SA (1999) Toxins from sea cucumbers (holothuroids): chemical structures, properties, taxonomic distribution, biosynthesis and evolution. J Nat Toxins 8:235-248

> Stowasser G, McAllen R, Pierce GJ, Collins MA, Moffat CF, Priede IG, Pond DW (2009) Trophic position of deep-sea 
fish: assessment through fatty acid and stable isotope analyses. Deep-Sea Res I 56:812-826

Volkman JK (1986) A review of sterol markers for marine and terrigenous organic matter. Org Geochem 9:83-99

Volkman JK (2003) Sterols in microorganisms. Appl Microb Biotechnol 60:495-506

Volkman JK, Nichols PD (1991) Applications of thin layer chromatography-flame ionization detection to the analysis of lipids and pollutants in marine and environmental samples. J Planar Chromatogr Mod TLC 4:19-26

Volkman JK, Jeffrey SW, Nichols PD, Rogers GI, Garland CD (1989) Fatty acid and lipid composition of 10 species of microalgae used in mariculture. J Exp Mar Biol Ecol 128: $219-240$

Editorial responsibility: Robert Feller, Columbia, South Carolina, USA
Votier SC, Furness RW, Bearhop S, Crane JE and others (2004) Changes in fisheries discard rates and seabird communities. Nature 427:727-730

> Yeh J, Drazen JC (2009) Depth zonation and bathymetric trends of deep-sea megafaunal scavengers of the Hawaiian Islands. Deep-Sea Res I 56:251-266

Young JW, Guest MA, Lansdell M, Phleger CF, Nichols PD (in press) Discrimination of prey species of juvenile swordfish Xiphias gladius (Linnaeus 1758) using signature fatty acid analyses. Prog Oceanogr

Zeidberg LD, Robison BH (2007) Invasive range expansion by the Humboldt squid, Dosidicus gigas, in the eastern North Pacific. Proc Natl Acad Sci USA 104: 12948-12950

Submitted: January 27, 2009; Accepted: May 7, 2009 Proofs received from author(s): June 17, 2009 